\title{
ANAEROBIC DIGESTION AND CO-DIGESTION OF POULTRY LITTER SUBMITTED TO DIFFERENT REUSES
}

\author{
Donizete J. Vicente Jr. ${ }^{1}$, Monica S. S. de M. Costa ${ }^{2 *}$, Luiz A. M. Costa ${ }^{1}$, \\ Dercio C. Pereira ${ }^{1}$, Francielly T. dos Santos ${ }^{1}$
}

2* Corresponding author. Research Group on Water Resources and Environmental Sanitation, Western Parana State University/Cascavel-PR, Brazil. E-mail: monicasarollisilva@gmail.com

\section{KEYWORDS}

Agroindustry, digestate, biogas, waste treatments.

\begin{abstract}
Considering the constant increase in the waste generation from poultry and pigs' husbandries, the main contributions of this study were to verify the potential of biogas production through the anaerobic digestion and co-digestion of the residues generated by these two activities, as well as to highlight the recovery of the nutrients contained in the obtained digestate. The wastes used were poultry litters after six, seven and eight production lots, as well as the sifted wastewater from one Piglets Producer Unit (PPU). Higher biogas production $(\mathrm{p}<0.05)$ was observed in the treatments in which anaerobic codigestion was used with the swine wastewater (SW): $0.179 ; 0.158$ and $0.117 \mathrm{~m}^{3}$ per $\mathrm{kg}$ of total solids (TS) added for poultry litters with six, seven and eight lots, respectively. It was concluded that the anaerobic co-digestion between the poultry litter and sifted swine wastewater is the best option for energy and nutrient recycling. No positive relationships were observed in the increase in the number of reuses of litter in the production of biogas and in the concentration of nutrients in the digestate.
\end{abstract}

\section{INTRODUCTION}

Brazil is the second largest producer of broiler chickens reaching 13.05 million tons in 2017. Of this amount, $66.9 \%$ attends the intern market and $33.1 \%$ is destined for exportation. The State of Paraná was responsible for $34.3 \%$ of this production and for $37.2 \%$ of the exports (ABPA, 2018).

The numbers of Brazilian pig farming, in spite of being smaller than those of the poultry industry, that are also significant. Brazil is the fourth largest producer of pork in the world with a production of 3.75 million tons in the year 2017. It also ranks fourth in the ranking of exports of the product. The State of Paraná also stands out in the production of pork with $21.01 \%$ of the total produced, ranking first among the Brazilian states in production and the third in export $(14.22 \%)$ behind the states of Rio Grande do Sul (29.47\%) and Santa Catarina (40.28\%) (ABPA, 2018).

These sectors, important from the trade balance point of view, also generate other by-products, the wastes, which value has increased due to the possibility of reuse for energy and fertilizer purposes.
The poultry litter is the main byproduct of the broiler chicken production, being responsible for avoiding the direct contact of the poultry with the floor, serving as substrate for water absorption, incorporation of feces, urine, feathers, skin scales and remains of food from the feedlot as well as contributes to the reduction of temperature fluctuations in the aviary (Markou, 2015). It can be made up of wood pellets, peanut shells, rice or other materials to absorb and facilitate the removal of wastes, as well as other materials generated during production (soil, feathers, insects, etc.) (Palma, 2012).

Regarding the amount of poultry litter generated, Santos \& Lucas Junior (2003) mentioned that on average each slaughtered chicken produced $2.19 \mathrm{~kg}$ of litter in the natural material (considering only two consecutive lots). Only in 2016 were slaughtered 5.79 billion of broiler chickens in slaughterhouse with federal, state or municipal inspection (IBGE, 2016), which would generate approximately 12.68 billion $\mathrm{kg}$ of poultry litter.

In Brazil, the favorable climate allows the construction of open aviaries with adequate conditions for the reuse of the litters, which depending of the material used and the adopted management can house up to fifteen lots, being commonly used six lots (Costa, 2009).

\footnotetext{
${ }^{1}$ Western Parana State University/Cascavel-PR, Brazil.

Received in: 10-9-2017

Accepted in: 8-25-2018
} 
The reuse of poultry litter for up to six lots improves its value as a fertilizer and reduces the $\mathrm{pH}$ of the litter. Due to animal production, and environmental standards and material shortages, the reuse of the poultry litter is already incorporated into the Brazilian broiler chicken production system (Dalólio et al., 2017). However, further studies are needed considering the changes in the poultry litter nutrient levels when reused for more than six lots in order to verify the environmental risks when using it in natura.

Swine wastewater (SW) also has great potential for pollution, and has been the subject of several studies on the impacts caused by its storage and use, such as the treatment in stabilization ponds or the use of fresh manure as fertilizer (Esposito et al., 2012; Wang et al., 2012a).

Although there are other technologies for the disposal of these wastes, anaerobic digestion has been a sustainable alternative for the disposal of various types of waste, mainly animal waste because of its high potential for methane production (Zhang et al., 2013), the possibility of producing renewable energy in biogas form and the possibility of nutrient recycling which are concentrated in the wastes (Zhang et al., 2012).

Other key points are the need to preserve the environment and the development of technologies capable of using less resources and minimizing impacts to the environment, besides the economic gain in the energy recovery of waste and the sanitary issue avoiding the spread of diseases (Palma, 2012).

Another variant of anaerobic digestion refers to the co-digestion of two or more wastes, performed with the objective of improving the physico-chemical properties of the raw material, making it more adequate and with a nutrient balance, resulting in better digestion efficiency and reaching high biogas production (Astals et al., 2011; Wang et al., 2012b).

For the purposes of co-digestion, the performance is determined by a number of factors, but the composition of the affluent or the proportion of the mixture are critical points due to the different characteristics of each waste (Murto et al., 2004). For example, in the study by Zhang et al. (2013) with the co-digestion of sewage sludge and dairy cattle manure, the highest yield of specific methane was found in relation to the wastes treated separately. However, the inadequate relationship in the mix of affluent to co-digestion could cause low performance of the digester.

Considering the above, the aims of this research were to evaluate the biogas production capacity in a batch test and the agronomic quality of the biofertilizer generated from the anaerobic digestion of poultry litter with different numbers of reuse and the co-digestion of the same ones with swine wastewater.

\section{MATERIAL AND METHODS}

\section{Experiment conditions and origin of wastes}

The experiment was conducted at the Laboratório de Análise de Resíduos Agroindustriais - LARA belonging to the Western Parana State University - UNIOESTE, located in the city of Cascavel, from February 27 to August 20, making 175 days of anaerobic digestion, at the time that the production of biogas was practically nil. The tests took place inside an enclosed room of approximately
$50 \mathrm{~m}^{2}$ protected from rain and wind. There was no temperature control in the environment, but this was monitored throughout the experiment when reading the biogas production.

The poultry litter (PL) used was collected in three aviaries from the region, all from the same integrator. The base of the PL was wood shavings and the material were obtained with 6, 7 and 8 lots of reuse.

Swine wastewater (SW) was obtained from a PPU (Piglet Production Unit) of the region. The collection was carried out after the separation of phases in a rotary sieve, which results in a liquid waste with less than $1 \%$ of total solids (TS).

Horizontal bench top digesters with a useful volume of $60 \mathrm{~L}$ were used. They were made of polyvinyl chloride (PVC) tubes $1 \mathrm{~m}$ long and $300 \mathrm{~mm}$ in diameter, with closed ends and holes, one on each side, used to feed and exit the substrate and an outlet for collecting the biogas. A plastic hose and a gasometer were also attached to the digester, also made in PVC pipes (Figure 1).

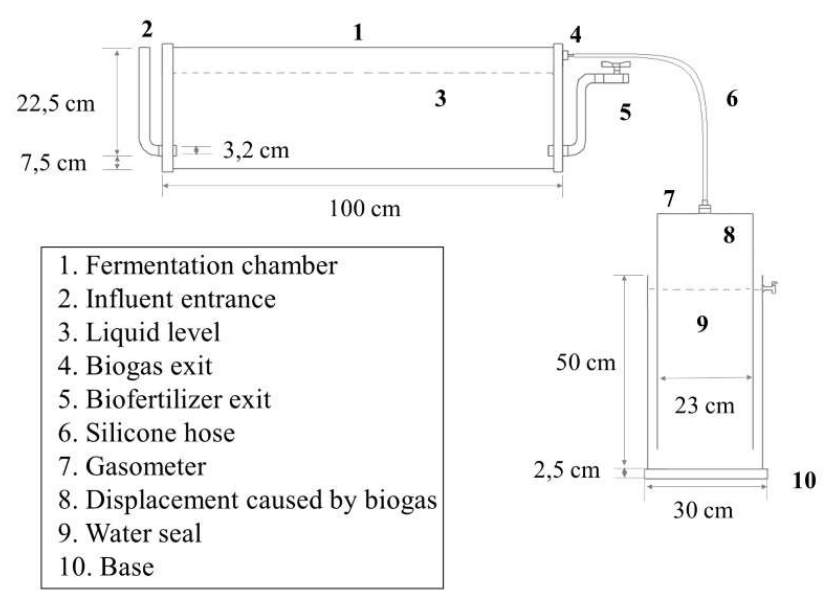

*Prototype developed at the Anaerobic Digestion Laboratory FCAV/UNESP

FONTE: Damaceno (2018)

FIGURE 1. Cross-sectional view of the digester and gasometer made from PVC pipes* for the use in the experiment

The treatments were defined according to the anaerobic digestion (AD) (AD6; AD7; AD8) or anaerobic co-digestion (CoAD) (CoAD6; CoAD7; CoAD8) using PL obtained after 6,7 and 8 lots of reuse in both processes. In the AD process $\mathrm{PL}+$ water + inoculum was used while in the CoAD process $\mathrm{PL}+\mathrm{SW}+$ inoculum was used. Manure of confined beef cattle was used as inoculum at a ratio of $15 \%$ (dry matter - DM). As a result, a substrate with TS in the range of 6 to $8 \%$ in DM was obtained.

The amounts of the components used in the preparation of the substrates are shown in Table 1.

TABLE 1. Quantities of substrate components in the supply of the batch digester.

\begin{tabular}{lccc}
\hline \multicolumn{1}{c}{ Components } & $\begin{array}{c}\text { 6 lots } \\
(\mathbf{k g})\end{array}$ & $\begin{array}{c}\mathbf{7 ~ l o t s} \\
(\mathbf{k g})\end{array}$ & $\begin{array}{c}\mathbf{8 ~ l o t s} \\
(\mathbf{k g})\end{array}$ \\
\hline Poultry Litter & 4.0 & 3.8 & 3.8 \\
Water or Swine wastewater & 54.8 & 55.0 & 55.0 \\
Inoculum & 1.2 & 1.2 & 1.2 \\
\hline
\end{tabular}




\section{Monitored parameters}

The daily production of biogas in the digesters was measured by water displacement using a gasometer of known dimensions. The value was submitted to a transformation equation and the result given in $\mathrm{m}^{3}$ day $^{-1}$ (Caetano, 1985), as described below:

$$
V_{0} P_{0} / T_{0}=V_{1} P_{1} / T_{1}
$$

In which:

$$
\begin{aligned}
& \boldsymbol{V}_{\boldsymbol{0}}=\text { corrected volume of biogas, } \mathrm{m}^{3} ; \\
& \boldsymbol{P}_{\boldsymbol{0}}=\text { corrected biogas pressure, } 10,322.72 \mathrm{~mm} \text { of } \mathrm{H}_{2} \mathrm{O} ;
\end{aligned}
$$

$\boldsymbol{T}_{\boldsymbol{0}}=$ corrected biogas temperature, $293.15^{\circ} \mathrm{K}$;

$V_{\boldsymbol{l}}=$ volume of gas in the gasometer;

$\boldsymbol{P}_{1}=$ biogas pressure at the time of reading, 9,393.49 $\mathrm{mm}$ of $\mathrm{H}_{2} \mathrm{O}$,

$\boldsymbol{T}_{\boldsymbol{1}}=$ biogas temperature at the time of reading, ${ }^{\circ} \mathrm{K}$

For characterization of the substrate and later of the biofertilizer, the variables presented in Table 2 with respective methodologies were determined.

TABLE 2. Methodologies for waste characterization.

\begin{tabular}{lc}
\hline \multicolumn{1}{c}{ Variables } & Methodology \\
\hline Oxigen Chemical Demand (OCD) & APHA, 2012 \\
Total Kjedahl Nitrogen (TKN) & Malavolta et al. (1997) \\
Total Solid (TS) and Volatile Solids (VS) & APHA, 2012 \\
pH and Electrical conductivity (EC) & Bench meter \\
Phosphorus (P) & Spectrometry (Malavolta et al., 1997) \\
Cellulose and Hemicellulose & Sequential method (Campos et al., 2004) \\
$\mathrm{K}, \mathrm{Ca}, \mathrm{Mg}, \mathrm{Zn}, \mathrm{Cu}, \mathrm{Fe}, \mathrm{Mn}$ & Atomic absorption after digestion in nitro-perchloric acid (EMBRAPA, 2009)
\end{tabular}

\section{Initial characteristics of the substrates}

For the initial characterization of the substrate, specific samples were made aiming greater homogeneity. The main

\begin{tabular}{|c|c|c|c|c|c|c|}
\hline \multirow[t]{2}{*}{ Substrate } & \multicolumn{3}{|c|}{ Co-digestion (PL + SW + inoculum) } & \multicolumn{3}{|c|}{ Digestion (PL + inoculum) } \\
\hline & CoAD6 & CoAD7 & CoAD8 & AD6 & AD7 & AD8 \\
\hline TS $(\%)$ & 7.3 & 7.3 & 7.2 & 6.3 & 6.2 & 6.4 \\
\hline $\operatorname{VS}(\%)^{*}$ & 74.8 & 73.3 & 77.5 & 79.0 & 69.9 & 80.5 \\
\hline $\mathrm{pH}$ & 7.7 & 7.7 & 7.8 & 7.9 & 8.0 & 8.1 \\
\hline $\mathrm{EC}(\mathrm{dS} / \mathrm{m})$ & 12.5 & 12.7 & 11.0 & 5.3 & 5.4 & 5.2 \\
\hline Cellulose (\%) & 46.6 & 47.3 & 46.1 & 55.1 & 50.3 & 53.1 \\
\hline Hemicellulose $(\%)$ & 34.6 & 33.6 & 28.9 & 36.0 & 31.2 & 29.7 \\
\hline N (\%) & 0.2 & 0.2 & 0.2 & 0.1 & 0.1 & 0.1 \\
\hline$P\left(g^{-1}\right)$ & 8.8 & 9.4 & 10.9 & 5.6 & 7.0 & 7.0 \\
\hline $\mathrm{K}\left(\mathrm{g} \mathrm{L}^{-1}\right)$ & 1.6 & 1.6 & 1.8 & 1.3 & 1.2 & 1.6 \\
\hline $\mathrm{Na}\left(\mathrm{g} \mathrm{L}^{-1}\right)$ & 0.8 & 0.8 & 0.8 & 0.2 & 0.2 & 0.3 \\
\hline $\mathrm{Ca}\left(\mathrm{g} \mathrm{L}^{-1}\right)$ & 4.2 & 4.6 & 5.1 & 3.8 & 4.1 & 4.4 \\
\hline $\operatorname{Mg}\left(g^{-1}\right)$ & 0.2 & 0.2 & 0.3 & 0.2 & 0.2 & 0.2 \\
\hline $\operatorname{Mn}\left(\mathrm{g} \mathrm{L}^{-1}\right)$ & 7.6 & 8.9 & 9.6 & 5.4 & 6.7 & 6.9 \\
\hline $\mathrm{Fe}\left(\mathrm{mg} \mathrm{L}^{-1}\right)$ & 31.1 & 35.3 & 37.6 & 22.3 & 37.5 & 28.4 \\
\hline $\mathrm{Zn}\left(\mathrm{mg} \mathrm{L}^{-1}\right)$ & 14.3 & 17.7 & 24.8 & 7.2 & 6.0 & 2.9 \\
\hline $\mathrm{Cu}\left(\mathrm{mg} \mathrm{L}^{-1}\right)$ & 10.2 & 15.7 & 16.0 & 1.4 & 1.1 & 1.7 \\
\hline $\mathrm{OCD}\left(\mathrm{mg} \mathrm{L}^{-1}\right)$ & 91,271 & 89,389 & 93,643 & 71,392 & 77,282 & 80,473 \\
\hline
\end{tabular}
chemical and physicochemical characteristics are presented in Table 3.

TABLE 3. Physicochemical analyzes of the substrates used in the AD and CoAD processes.

* Percentage of volatile solids in relation to the total solids amount. 


\section{Experimental design and statistical analysis}

The experiment was conducted using a completely randomized design. The data were analyzed using analysis of variance (ANOVA) followed by the Tukey's multiple comparison test $(\mathrm{p} \leq 0.05)$.

\section{RESULTS AND DISCUSSION}

\section{Biogas Production Potential}

The average biogas production potentials obtained in the experiment are presented in Table 4.

TABLE 4. Biogas Production Potentials in the $\mathrm{AD}$ and CoAD processes.

\begin{tabular}{ccccc}
\hline & $\begin{array}{c}\text { Total Volume } \\
\left(\mathrm{m}^{3}\right)\end{array}$ & $\begin{array}{c}\text { Biogas per kg of PLadded } \\
\left(\mathrm{m}^{3} \mathrm{~kg}^{-1}\right)\end{array}$ & $\begin{array}{c}\text { Biogas per kg of TS } \\
\left(\mathrm{m}^{3} \mathrm{~kg}^{-1}\right)\end{array}$ & $\begin{array}{c}\text { Biogas per kg of VS } \\
\left(\mathrm{m}^{3} \mathrm{~kg}^{-1}\right)\end{array}$ \\
\hline CoAD6 & $0.79 \mathrm{~A} \mathrm{a}$ & $0.197 \mathrm{~A} \mathrm{a}$ & $0.179 \mathrm{~A} \mathrm{a}$ & $0.241 \mathrm{~A} \mathrm{a}$ \\
\hline CoAD7 & $0.69 \mathrm{~A} \mathrm{ab}$ & $0.181 \mathrm{~A} \mathrm{ab}$ & $0.158 \mathrm{~A} \mathrm{a}$ & $0.217 \mathrm{~A} \mathrm{a}$ \\
\hline CoAD8 & $0.50 \mathrm{~A} \mathrm{~b}$ & $0.133 \mathrm{~A} \mathrm{~b}$ & $0.117 \mathrm{~A} \mathrm{~b}$ & $0.151 \mathrm{~A} \mathrm{~b}$ \\
\hline AD6 & $0.09 \mathrm{~B} \mathrm{~b}$ & $0.022 \mathrm{~B} \mathrm{~b}$ & $0.023 \mathrm{~B} \mathrm{~b}$ & $0.030 \mathrm{~B} \mathrm{~b}$ \\
\hline AD7 & $0.43 \mathrm{~B} \mathrm{a}$ & $0.112 \mathrm{~B} \mathrm{a}$ & $0.115 \mathrm{~B} \mathrm{a}$ & $0.166 \mathrm{~B} \mathrm{a}$ \\
\hline AD8 & $0.06 \mathrm{~B} \mathrm{~b}$ & $0.015 \mathrm{~B} \mathrm{~b}$ & $0.015 \mathrm{~B} \mathrm{~b}$ & $0.020 \mathrm{~B} \mathrm{~b}$ \\
\hline
\end{tabular}

Capital letters represent a comparison of the potentials between the AD and CoAD processes; lowercase letters represent a comparison of the potentials between the reuse number of $\mathrm{PL}$ within each process (AD or CoAD).

Different significantly when $\mathrm{p}$-value $<0.05$.

The comparison of the results obtained with others in the literature can be compromised due to the various peculiarities of each production system. For example, the results obtained by Santos (2001) who evaluated the effect of the broilers density (22, 16 and 10 broilers $\mathrm{m}^{-2}$ ) on experimental and commercial aviary, after one and two lots of reuse. The author observed that the results obtained in the batch assay for biogas production potentials varied from 0.1738 to $0.2329 \mathrm{~m}^{3}$ of biogas per $\mathrm{kg}$ of $\mathrm{TS}_{\text {added }}$ (experimental aviary) and 0.1418 to $0.2966 \mathrm{~m}^{3}$ of biogas per $\mathrm{kg} \mathrm{TS}_{\text {added }}$ (commercial aviary).

However, two factors should be highlighted: the increase in biogas production when PL is co-digested with SW and the fact that no correlation was observed between the production of biogas and the increase in the number of PL reuse.

Regarding the first factor, CoAD with SW, a $96 \%$ increase in the production of biogas per $\mathrm{kg}$ of $\mathrm{TS}_{\text {added }}$ can be observed, which demonstrates the synergistic effect among the wastes. In experimental conditions in Brazil, the closest research involves $\mathrm{AD}$ and $\mathrm{CoAD}$ of $\mathrm{PL}$ which base was pine sawdust after only one lot (Costa, 2009). The treatments involved three situations: PL + biofertilizer from pigs + water (1), PL + biofertilizer from swine manure (2) and PL + water (3). The author concluded that the two treatments in which CoAD was adopted presented the highest biogas production potential $(0.327$ and 0.3031 $\mathrm{m}^{3}$ biogas $\mathrm{kg}^{-1} \mathrm{TS}_{\text {added }}$ for treatments 1 and 2, respectively) when compared to the $\mathrm{AD}\left(0.2295 \mathrm{~m}^{3}\right.$ biogas $\left.\mathrm{kg}^{-1} \mathrm{TS}_{\text {added }}\right)$, that is, an average increase of $37.3 \%$ in favor of CoAD.

However, when compared to the influence of the number of PL reusing (lots) within each process, the PL that received six lots produced a larger amount of biogas than the PL that received eight lots in the CoAD process. As for the $\mathrm{AD}$ process, the PL that received seven lots presented the highest potentials. The non-observance of effect in relation to the increase in the number of lots may be explained by the origin of the poultry litters, since these were collected in different aviaries, although the same integrator.

\section{Distribution of biogas production}

In Figure 2, the average distribution of biogas production in the experiment over time can be observed.

Figure 2 shows the peak of biogas production in the CoAD6 treatment as early as the second week after installation. It is also observed that the other two treatments under CoAD, CoAD8 and CoAD7 present the peaks of production in the third and fourth week, respectively. The continuous biogas burning in these treatments occurred on the $10^{\text {th }}$ day for CoAD6, on the $15^{\text {th }}$ day for CoAD7 and on the $18^{\text {th }}$ day CoAD8. Already for the treatments submitted to the $\mathrm{AD}$ process the continuous biogas burning occurred on the $35^{\text {th }}$ day for AD6 and AD7 and $36^{\text {th }}$ day for AD8. Continuous burning of biogas means that at least $50 \%$ of its composition is methane. After the first 90 days, approximately, the stabilization of the process was verified, characterizing the decrease of the production.

In the $\mathrm{AD} 6$ and $\mathrm{AD} 8$ treatments, low biogas production is observed during the experimental period. Only AD7 treatment shows a peak production at week 8 . The most acceptable explanation for this behavior is the synergistic effect between PL and SW contained in the treatments submitted to CoAD. In this sense, Zahan et al. (2018) submitted PL to AD and compared the results with their CoAD in mixture with other agro-industrial wastes. The authors concluded that during CoAD, methane production was increased by $9-85 \%$ by the addition of two, three or four substrates due to the synergistic effect as a result of increased biodegradability and optimum conditions (as $\mathrm{C}: \mathrm{N}$ ratio). 


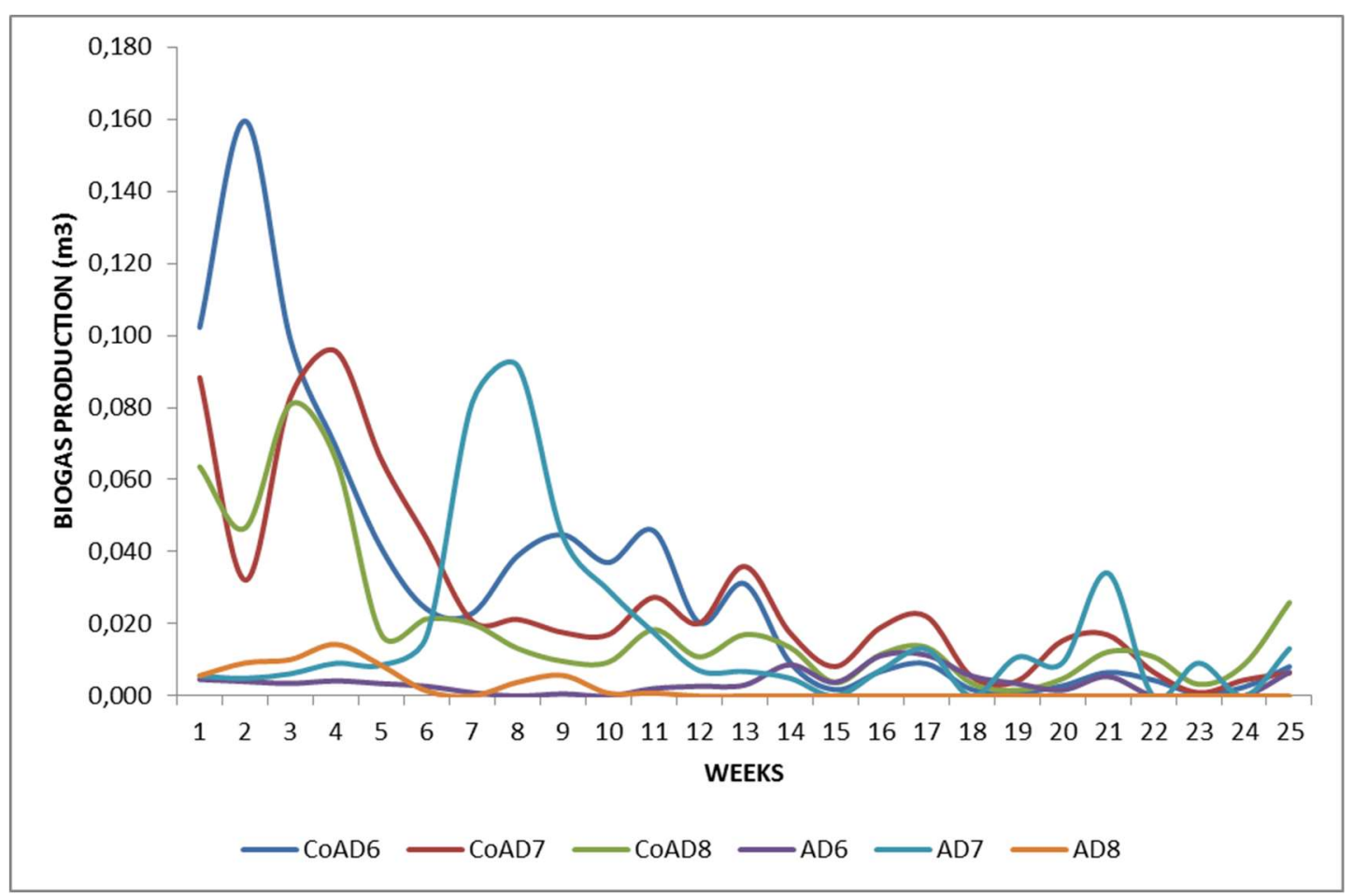

FIGURE 2. Weekly distribution of biogas production in treatments submitted to CoAD and AD of poultry litter $(\mathrm{HRT}=175$ days).

Another probable explanation refers to the use of different chemical treatments in PL since they came from different aviaries, although the same integrator. In CoAD, the effects are minimized due to the presence of SW. Ebner et al. (2016) mention that CoAD promotes a dilution of inhibitory effects. We observed that even in CoAD, PLs with 7 and 8 lots presented decrease in production at the $2^{\text {nd }}$ week and subsequent recovery. Further studies should be carried out to elucidate the effects of the chemical treatments performed on PL in the CoAD and $\mathrm{AD}$ processes.

Also in this sense, a significant reduction was observed in the $\mathrm{pH}$ values of the biofertilizers obtained in the treatments that were submitted to the DA process (Tables 5 and 6). At the end of the CoAD and $\mathrm{AD}$ processes, an increase in $\mathrm{pH}$ values is expected. Sutaryo et al. (2012) and Zonta et al. (2013) comment that with the formation of acids at the beginning of the fermentative phase it is observed a reduction of the $\mathrm{pH}$ of the medium to 6 or less. Then, with the degradation of the volatile acids there is a gradual increase of the $\mathrm{pH}$ due to the production of $\mathrm{CH}_{4}$ by the methanogenic archaea. As the $\mathrm{pH}$ values of the biofertilizers decreased it can be inferred that there was accumulation of the volatile organic acids to the point of inhibiting the methanogenic activity.

\section{Mineral characterization of effluents}

The chemical characteristics of the effluent (biofertilizer) are described in Table 5. Thus, it is possible to verify an increase in the concentration of most nutrients at the end of the process, which occurs due to the transformation of $\mathrm{C}$ into $\mathrm{CO}_{2}$ and $\mathrm{CH}_{4}$ that are volatile. In the treatments submitted to $\mathrm{CoAD}$, higher concentrations of nutrients were observed when compared to treatments submitted to $\mathrm{AD}$, due to the significant contribution of nutrients from SW. The EC increase during the CoAD and $\mathrm{AD}$ processes corroborate the effect on nutrient concentration.

Important increases in nutrient concentration are observed when the results obtained in the treatments submitted to $\mathrm{CoAD}$ and $\mathrm{AD}$ are compared. In the biofertilizers from the CoAD process, $\mathrm{N}$ concentrations were $92 \%$ higher, $\mathrm{P}$ were $86.6 \%, \mathrm{~K}$ were $26.9 \%$ and $\mathrm{Ca}$ were $20.2 \%$ higher, but for $\mathrm{Mg}$ there was no change.

Considering the micronutrients, Fe presented $79.9 \%$ higher, $\mathrm{Mn} 84.8 \%$, Zn 270.1\% and $\mathrm{Cu} 904.7 \%$. The $\mathrm{Na}$ element presented $55.2 \%$ higher for the biofertilizers obtained by CoAD when compared to the biofertilizers obtained in the DA process.

Considering these results, some elements may limit the agricultural use of biofertilizer produced with the use of SW, they are $\mathrm{Cu}, \mathrm{Zn}$ and $\mathrm{Na}$. Girotto et al. (2010) aimed to estimate the accumulation of $\mathrm{Cu}$ and $\mathrm{Zn}$ and their forms in soil subjected to successive applications of liquid swine manure in a no-tillage system with crop rotation. The authors comment that CETESB (2001) establishes maximum values of 100 and $500 \mathrm{mg} \mathrm{kg}^{-1}$ for $\mathrm{Cu}$ and $\mathrm{Zn}$ for agricultural soils, respectively. However, Na may cause soil structure degradation at high concentrations due to the dispersion of clay particles and contribute to their densification due to pore blockade (Albuquerque, 2012; Restrepo et al., 2013). However, the limitation of the use of the digestate from CoAD of $\mathrm{PL}$ and $\mathrm{SW}$ can be overcome by decreasing the dose applied to each crop. With this, other benefits such as acidity correction and the supply of other nutrients are guaranteed. 
TABLE 5. Mineral characterization of the affluent (A) and effluent (E) after 175 days of HRT.

\begin{tabular}{|c|c|c|c|c|c|c|}
\hline & \multicolumn{2}{|c|}{ CoAD6 } & \multicolumn{2}{|c|}{ CoAD7 } & \multicolumn{2}{|c|}{ CoAD8 } \\
\hline & $\mathbf{A}$ & $\mathbf{E}$ & $\mathbf{A}$ & $\mathbf{E}$ & $\mathbf{A}$ & $\mathbf{E}$ \\
\hline $\mathrm{pH}$ & 7.75 & 7.87 & 7.75 & 7.86 & 7.80 & 7.72 \\
\hline $\mathrm{EC}\left(\mathrm{dS} \mathrm{m}^{-1}\right)$ & 12.52 & 15.94 & 12.70 & 14.48 & 11.05 & 15.45 \\
\hline $\mathrm{N}(\%)$ & 0.22 & 0.26 & 0.21 & 0.20 & 0.19 & 0.24 \\
\hline $\mathrm{P}\left(\mathrm{g} \mathrm{L}^{-1}\right)$ & 8.75 & 10.10 & 9.40 & 14.60 & 10.92 & 16.38 \\
\hline $\mathrm{K}\left(\mathrm{g} \mathrm{L}^{-1}\right)$ & 1.56 & 1.81 & 1.58 & 1.71 & 1.78 & 1.85 \\
\hline $\mathrm{Na}\left(\mathrm{g} \mathrm{L}^{-1}\right)$ & 0.75 & 0.47 & 0.76 & 0.46 & 0.82 & 0.43 \\
\hline $\mathrm{Ca}\left(\mathrm{g} \mathrm{L}^{-1}\right)$ & 4.22 & 5.87 & 4.61 & 6.16 & 5.10 & 5.87 \\
\hline $\mathrm{Mg}\left(\mathrm{g} \mathrm{L}^{-1}\right)$ & 0.21 & 0.22 & 0.23 & 0.40 & 0.27 & 0.26 \\
\hline $\operatorname{Mn}\left(\mathrm{mg} \mathrm{L}^{-1}\right)$ & 7.57 & 20.42 & 8.93 & 22.76 & 9.63 & 11.62 \\
\hline $\mathrm{Fe}\left(\mathrm{mg} \mathrm{L}^{-1}\right)$ & 31.05 & 45.56 & 35.33 & 82.18 & 37.64 & 30.92 \\
\hline $\mathrm{Zn}\left(\mathrm{mg} \mathrm{L}^{-1}\right)$ & 14.34 & 37.77 & 17.70 & 47.83 & 24.77 & 22.15 \\
\hline $\mathrm{Cu}\left(\mathrm{mg} \mathrm{L}^{-1}\right)$ & 10.21 & 19.17 & 15.74 & 21.41 & 16.04 & 10.65 \\
\hline
\end{tabular}

TABLE 5 (continuation).

\begin{tabular}{|c|c|c|c|c|c|c|}
\hline & \multicolumn{2}{|c|}{ AD6 } & \multicolumn{2}{|c|}{ AD7 } & \multicolumn{2}{|c|}{ AD8 } \\
\hline & A & $\mathbf{E}$ & A & $\mathbf{E}$ & $\mathbf{A}$ & $\mathbf{E}$ \\
\hline$\overline{\mathrm{pH}}$ & \begin{tabular}{|l}
7.93 \\
\end{tabular} & 6.87 & 8.00 & 7.65 & 8.09 & 5.46 \\
\hline $\mathrm{EC}\left(\mathrm{dS} \mathrm{m^{-1 } )}\right.$ & 5.35 & 9.30 & 5.39 & 7.96 & 5.23 & 11.76 \\
\hline $\mathrm{N}(\%)$ & 0.10 & 0.13 & 0.10 & 0.09 & 0.13 & 0.13 \\
\hline $\mathrm{P}\left(\mathrm{g} \mathrm{L}^{-1}\right)$ & 5.58 & 6.18 & 6.98 & 6.52 & 7.02 & 9.33 \\
\hline $\mathrm{K}\left(\mathrm{g} \mathrm{L}^{-1}\right)$ & 1.28 & 1.34 & 1.20 & 1.32 & 1.58 & 1.57 \\
\hline $\mathrm{Na}\left(\mathrm{g} \mathrm{L}^{-1}\right)$ & 0.25 & 0.26 & 0.24 & 0.30 & 0.27 & 0.32 \\
\hline $\mathrm{Ca}\left(\mathrm{g} \mathrm{L}^{-1}\right)$ & 3.84 & 4.19 & 4.09 & 4.85 & 4.39 & 5.84 \\
\hline $\mathrm{Mg}\left(\mathrm{g} \mathrm{L}^{-1}\right)$ & 0.16 & 0.30 & 0.18 & 0.21 & 0.19 & 0.37 \\
\hline $\mathrm{Mn}\left(\mathrm{mg} \mathrm{L}^{-1}\right)$ & 5.41 & 10.18 & 6.69 & 3.59 & 6.86 & 15.95 \\
\hline $\mathrm{Fe}\left(\mathrm{mg} \mathrm{L}^{-1}\right)$ & 22.27 & 21.12 & 37.47 & 33.35 & 28.39 & 33.80 \\
\hline $\mathrm{Zn}\left(\mathrm{mg} \mathrm{L}^{-1}\right)$ & 7.21 & 7.28 & 5.98 & 6.30 & 2.94 & 15.60 \\
\hline $\mathrm{Cu}\left(\mathrm{mg} \mathrm{L}^{-1}\right)$ & 1.35 & 1.52 & 1.13 & 1.36 & 1.72 & 2.22 \\
\hline
\end{tabular}

It is noted, however, that a linear pattern of increase in nutrient concentration was not observed as a function of the increase in the number of PL reuses. This result may be due to the difficulty of sampling the digestate as a function of the heterogeneity of the material, with fast sedimentation of the material at the time of collection.

Therefore, from these analyzes, it can be stated that the PL CoAD process with SW provides not only an effluent with higher biogas production potentials, but also higher nutrient contents, adding agronomic value besides energy when compared with the $\mathrm{AD}$ process. However, due to the increase in $\mathrm{Cu}$ and $\mathrm{Zn}$ by SW contribution, the need for environmental care in its agronomic use was revealed.

\section{CONCLUSIONS}

The anaerobic co-digestion of poultry litter and swine wastewater has advantages over mono-digestion. The benefits involve higher biogas production potential and higher agronomic value of the digestate.

No positive relationships were observed in the increase in the number of reuses of poultry litter in the production of biogas and in the concentration of nutrients in the digestate.
Due to the presence of swine wastewater in the anaerobic co-digestion process, there is a higher concentration of $\mathrm{Cu}$ and $\mathrm{Zn}$ in the biofertilizer, which requires an environmentally safe recommendation of this material.

\section{REFERENCES}

ABPA - Associação Brasileira de Proteína Animal (2018) Relatório anual de 2017. São Paulo, ABPA.

APHA (2012) Standard methods for the examination of water and wastewater. Washinton, American Public Health Association, American Water Works Association, Water Environment Federation, $32^{\text {th }}$ ed.

Astals S, Ariso M, Galí A, Mata-Alvarez J (2011) Codigestion of pig manure and glycerine: Experimental and modelling study. Journal of Environmental Management 92:1091-1096.

Campos FP, Nussio CMB, Nussio LG (2004) Métodos de análise de alimentos. Piracicaba, FEALQ, 135 p.

Caetano L (1985) Proposição de um sistema modificado para quantificação de biogás. Dissertação Mestrado, Botucatu, Universidade Estadual Paulista, Faculdade de Ciências Agronômicas. 
CETESB - Companhia de Tecnologia de Saneamento Ambiental (2001) Relatório de estabelecimento de valores orientadores para solos e águas subterrâneas, São Paulo.

Costa LVC da (2009) Biodigestão Anaeróbia da Cama de Frango Associada ou não ao Biofertilizante Obtido com Dejetos de Suínos: Produção de Biogás e Qualidade do Biofertilizante. 87f. Dissertação Mestrado, Jaboticabal, Universidade Estadual Paulista, Faculdade de Ciências Agrárias e Veterinárias.

Dalólio FS, Silva JN, Oliveira ACC, Tinôco IDEFF, Barbosa RC, Resende M de O, Albino LFT, Coelho ST (2017) Poultry litter as biomass energy: A review and future perspectives. Renewable and Sustainable Energy Reviews 76:941-949.

Ebner JH, Labatut RA, Lodge JS, Williamson AA, Trabold TA (2016) Anaerobic co-digestion of commercial food waste and dairy manure: Characterizing biochemical parameters and synergistic effects. Waste Management 52:286-294.

EMBRAPA - Empresa Brasileira de Pesquisa Agropecuária (2009) Manual de análises químicas de solos, plantas e fertilizantes. Embrapa, 2 ed.

Esposito G, Frunzo L, Panico A, Pirozzi F (2012) Enhanced bio-methane production from co-digestion of different organic wastes. Environmental Technology $33: 2733-2740$.

Girotto E, Ceretta CA, Brunetto G, Santos DR, Silva LS, Lourenzi CR, Lorensini F, Vieira RCB, Schmatz R (2010) Acúmulo e formas de cobre e zinco no solo após aplicações sucessivas de dejeto líquido de suínos. Revista Brasileira de Ciência do Solo 34:955-965.

IBGE - Instituto brasileiro de Geografia e Estatística (2016) Em 2015, abate de suínos e de frangos bate recorde, mas o abate de bovinos e as aquisições de leite e de couro recuam. Available in:

https://agenciadenoticias.ibge.gov.br/agencianoticias/2013-agencia-de-noticias/releases/9568-em-2015abate-de-suinos-e-de-frangos-bate-recorde-mas-o-abatede-bovinos-e-as-aquisicoes-de-leite-e-de-courorecuam.html. Accessed: Aug 22, 2018.

Malavolta E, Vitti GC, Oliveira SA (1997) Avaliação do estado nutricional das plantas: princípios e aplicações. 2. ed. Piracicaba, POTAFOS, 2 ed. 319 p.

Markou G (2015) Improved anaerobic digestion performance and biogas production from poultry litter after lowering its nitrogen content. Bioresource Technology 196:726-730. DOI: http://dx.doi.org/10.1016/ j.biortech.2015.07.067

Murto M, Bjornsson L, Mattiasson B (2004) Impact of food industrial waste on anaerobic co-digestion of sewage sludge and pig manure. Journal of Environmental Management 70:101-107.
Palma CF (2012) Characterisation, kinetics and modelling of gasification of poultry manure and litter: An overview. Energy Conversion and Management 53:92-98.

Restrepo AP, Medina E, Pérez-Espinosa A, Agulló E, Bustamante MA, Mininni C, Bernal MP, Moral R (2013) Substitution of Peat in horticultural seedlings: suitability of digestate-derived compost from cattle manure and maize silage codigestion. Communications Soil Science Plant Analysis 44:668-677.

Santos TMBD (2001) Balanço energético e adequação do uso de biodigestores em galpões de frangos de corte. Tese Doutorado, Jaboticabal, Universidade Estadual Paulista, Faculdade de Ciências Agrárias e Veterinárias.

Santos TMB, Lucas Junior J (2003) Utilização de resíduos da avicultura de corte para a produção de energia. In: Congresso Internacional de Zootecnia, 5 Congresso Nacional de Zootecnia. Uberaba. Anais...

Sutaryo S, Ward AJ, Møller HB (2012) Thermophilic anaerobic co-digestion of separated solids from acidified dairy cow manure. Bioresource Technology 114:195-200.

Wang X, Yang Y, Feng Y, Ren G, Han X (2012a) Optimizing feeding composition and carbon-nitrogen ratios for improved methane yield during anaerobic codigestion of dairy, chicken manure and wheat straw. Bioresource Technology 120:78-83.

Wang XJ, Yang GH, Feng YZ, Ren G, Han X (2012b) Potential for biogas production from anaerobic codigestion of dairy and chicken manure with corn stalks. Advanced Materials Research 347:2484-2492.

Zahan Z, Othman MZ, Muster TH (2018) Anaerobic digestion/co-digestion kinetic potentials of different agroindustrial wastes: A comparative batch study for $\mathrm{C} / \mathrm{N}$ optimization. Waste Management 71:663-674.

Zhang Y, Banks CJ, Heaven S (2012) Co-digestion of source segregated domestic food waste to improve process stability. Bioresource Technology 114:168-178.

Zhang C, Xiao G, Peng L, Su H, Tan T (2013) The anaerobic co-digestion of food waste and cattle manure. Bioresource Technology 129:170-176.

Zonta Z, Alves MM, Flotats X, Palatsi J (2013) Modeling inhibitory effects of long chain fatty acid sinthean aerobic digestion process. Water Research 47:1369-80. 